\title{
A Critical Evaluation of Anti-IL-13 and Anti-IL-4 Strategies in Severe Asthma
}

\author{
Diego Bagnasco $^{a}$ Matteo Ferrando ${ }^{a}$ Gilda Varricchi $^{\mathrm{b}}$ Giovanni Passalacqua $^{\mathrm{a}}$ \\ Giorgio Walter Canonica ${ }^{a}$

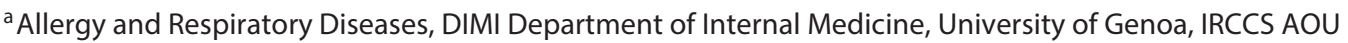 \\ San Martino-IST, Genoa, and b Division of Clinical Immunology and Allergy, Department of Translational Medical \\ Sciences, University of Naples Federico II, Naples, Italy
}

\section{Key Words}

Severe asthma $\cdot$ Monoclonal antibodies · Interleukins .

Biomarkers · T helper 2 endotype · Personalized medicine

\begin{abstract}
Asthma is a high-prevalence disease, still accounting for mortality and high direct and indirect costs. It is now recognized that, despite the implementation of guidelines, a large proportion of cases remain not controlled. Certainly, adherence to therapy and the education of patients remain the primary objective, but the increasingly detailed knowledge about the pathogenic mechanisms and new biotechnologies offer the opportunity to better address and treat the disease. Interleukin (IL)-13 and IL-4 appear as the most suitable targets to treat the Thelper 2 (TH2)-mediated forms (endotypes) of asthma. IL-13 and IL-4 partly share the same receptor and signaling pathways and both are deeply involved in immunoglobulin E (IgE) synthesis, eosinophil activation, mucus secretion and airways remodeling. Several anti-IL-13 strategies have been proposed (anrukinzumab, lebrikizunab and tralokinumab), with relevant clinical results reported with lebrikizumab. Such studies facilitate better definition of the possible predictive markers of response to a specific treatment (e.g. eosinophils, total lgE, fraction of exhaled ni-
\end{abstract}

tric oxide and periostin). In parallel, anti-IL-4 strategies have been attempted (pascolizumab, pitakinra and dupilumab). So far, dupilumab was reported capable of reducing the severity of asthma and the rate of exacerbations. IL-13 and IL-4 are crucial in TH2-mediated inflammation in asthma, but it remains clear that only specific endotypes respond to these treatments. Although the use of anti-IL-14 and anti-IL-13 strategies is promising, the search for appropriate predictive biomarkers is urgently needed to better apply biological treatments.

(c) 2016 S. Karger AG, Basel

\section{Introduction}

Asthma is a high-prevalence, chronic disease. In fact, in the USA, it affects about 24.6 million and worldwide about 334 million of people of all ages [1]. Although the mortality for asthma is decreasing overall [2], it still accounts for 90-170 deaths per million. In addition, direct (e.g. hospital care and drugs) and indirect (e.g. loss of work or school days) costs still represent a major burden of the disease. The cost per year for a European patient has been estimated at 509 euros for controlled asthma and 2,281 euros for uncontrolled asthma [3]. Although asth-

\section{KARGER}

E-Mail karger@karger.com

www.karger.com/iaa
(C) 2016 S. Karger AG, Basel

$1018-2438 / 16 / 1702-0122 \$ 39.50 / 0$
Correspondence to: Prof. Giorgio W. Canonica

Allergy and Respiratory Diseases, DIMI Department of Internal Medicine University of Genoa, IRCCS AOU San Martino-IST

Largo Rosanna Benzi 10, IT-16132 Genoa (Italy)

E-Mail canonica@unige.it 
ma can be frequently controlled with the standard inhalant therapy, clinical trials report that in about $20 \%$ of patients using traditional drugs, asthma remains not controlled [4], and the situation is even worse in real life. On the other hand, the idea that asthma is a single disease has been recently questioned, and it is now considered as a heterogeneous disease with different pathogenic mechanisms, clinical behaviors and responses to treatment.

The process of asthma phenotyping started about 10 years ago, with the aim of identifying homogeneous groups (either clinically or biologically) of patients. More recently, the term 'endotype' was introduced to underline a more in-depth identification of asthma, including the genetic aspects. Nowadays, $>100$ genes related to the pathogenesis of asthma have been identified, but the road to fully understand the genetic contribution seems to still be long and tortuous, since no 'asthma gene' has been identified so far. In recent years, it was realized that different phenotypes can be characterized by specific molecular patterns, possibly predictive of the response to specific treatments. The most apparent example is the discovery of the role played by T helper 2 (TH2) lymphocyte-mediated inflammation (so-called 'TH2 high') in about half of asthmatic subjects. Subsequently, more clinical trials have been conducted targeting those molecules specifically related to $\mathrm{TH} 2$ inflammation. For instance, clinical trials with biological agents against TH2-associated cytokines consistently show a more remarkable efficacy in patients with markers of elevated TH2 inflammation, such as eosinophils $[5,6]$.

Despite the use of guideline recommendations for management and therapy, a relevant number of patients continue to report an unsatisfactory control of asthma, with impaired quality of life, exacerbations, increased use of rescue medications or systemic corticosteroids and emergency room/intensive care unit admission. It is noteworthy that in about $50 \%$ of these patients there is strong evidence of the pathogenic role of TH2 cytokines such as interleukin (IL)-4, IL-5 and IL-13 orchestrating the eosinophilic and allergic inflammatory processes [7].

\section{The Role of IL-13 and IL-4}

IL-4 and IL-13 were among the first TH2-related interleukins discovered in the early 1980s and, since then, they have been traditionally associated with atopy and allergic diseases in general but are also involved in pregnancy, fetal development, mammary development, lactation and various neuronal functions including cognitive

Anti-IL-13 and Anti-IL-4 Strategies in Severe Asthma and learning processes and memory formation [8-10]. In theory, every cell has the potential to respond to IL-4, IL13 or both, but some cell types seem to be more susceptible [11].

We have described the relevance of IL-13 and IL- 4 in the pathophysiology of asthma, concerning the proliferation of bronchial fibroblasts, myofibroblasts and airway smooth muscle cells, which leads to airway remodeling $[12,13]$. An IL-13 induced role in goblet cell differentiation, mucus production, bronchial hyperresponsiveness, immunoglobulin E (IgE) synthesis (a switch of B cell antibody production) and the recruitment of eosinophils and basophils [14-20] has been repeatedly demonstrated [21].

Several clinical trials have highlighted the role of antiIL-13 biological agents in the control of disease in the 'TH2 high' asthmatic phenotype which is characterized by an overexpression of IL-13 inducible genes such as periostin [6]. The role of $\mathrm{TH} 2$ inflammation is apparent in about $50 \%$ of asthmatic patients, in whom there is an abnormal production of proinflammatory cytokines, such as IL-4, IL-5 and IL-13, which induce IgE synthesis and eosinophilic inflammation [22]. TH2 effector cells, once activated by stimulating factors such as allergens, pollutants or infectious agents, release the aforementioned cytokines which act on the surface cells. Several studies have demonstrated that the production of IL-4, IL-5 and IL-13 is associated with the response of type- 2 innate lymphoid cells (ILC2s) to IL-25, IL-33, thymic stromal lymphopoietin (TSLP) and leukotrienes [23]. High concentrations of ILC2s have been shown in patients with nasal polyposis and/or a high eosinophil blood count $[6,24]$.

IL-4 was discovered in the 1980s. It is secreted by activated $\mathrm{T}$ cells, mast cells, basophils and eosinophils [25]. There is a close link between IL- 4 and IL-13 activity: both activate the $\alpha$-subunit of the IL- 4 receptor (IL-4R $\alpha$ ), and IL- 4 also activates a $\gamma \mathrm{C}$ subunit while IL- 13 stimulates the IL-13 receptor a1 subunit (IL-13Ra1) [26]. The role of IL-4 is linked to TH2 phenotype lymphocytes. It regulates the synthesis of IgE by B cells and the apoptosis and expression of numerous genes involved in the maturation of macrophages, fibroblasts, epithelial and endothelial cells [27] (fig. 1).

\section{Overview of IL-4/IL-13 Receptor Signaling}

Circulating IL-4 and IL-13 bind to a specific receptor which is expressed on various cells, including B lymphocytes, eosinophils, basophils, monocytes and macrophages, dendritic cells, endothelial cells, fibroblasts, air- 


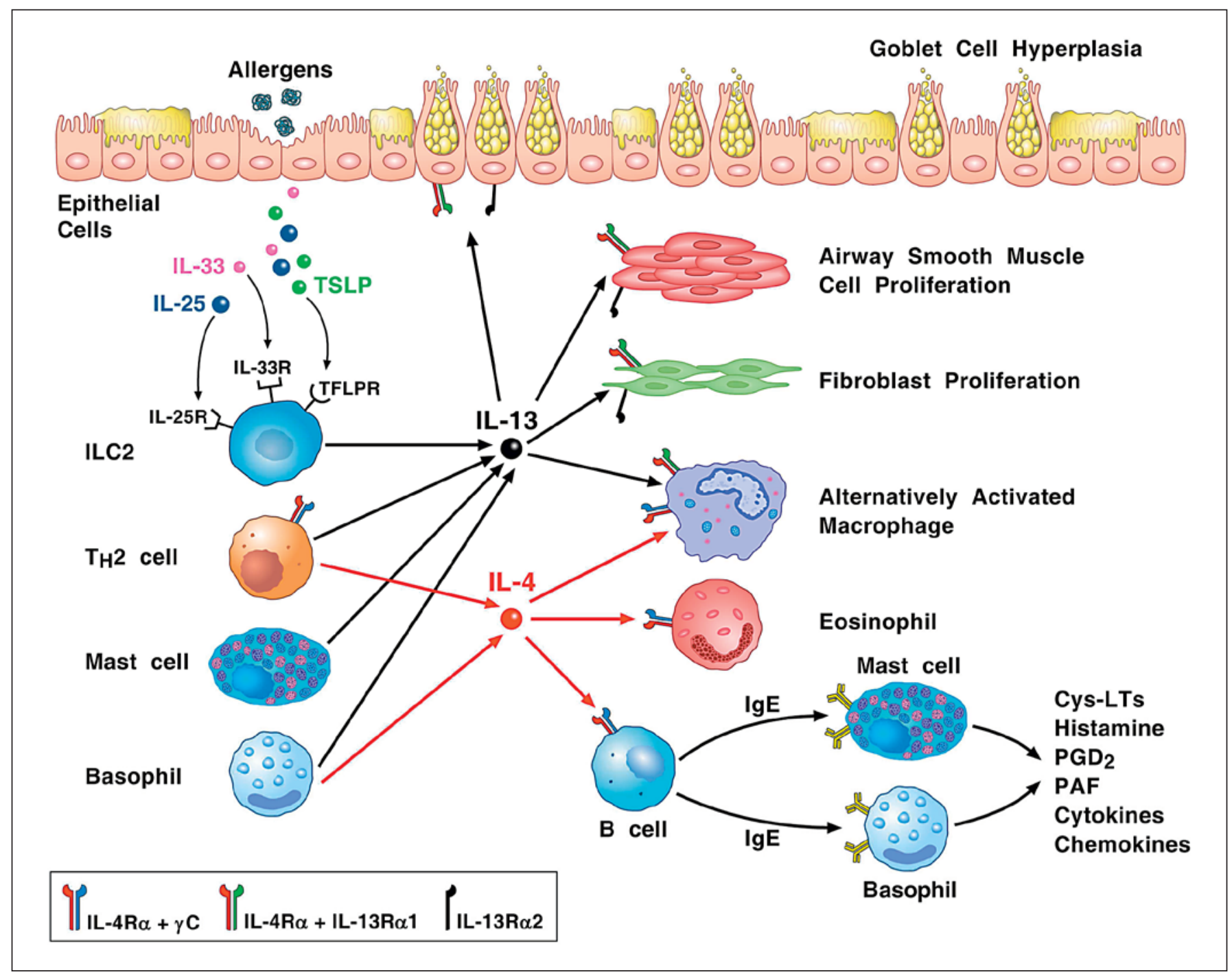

Fig. 1. Diagram of the potential cellular effects of IL-4 and IL-13 on inflammatory and structural cells in asthma. After interaction with noxious agents, including allergens, viruses and proteases, pulmonary epithelial cells can produce TSLP, IL-25 and IL-33. These cytokines activate specific receptors on ILC2s and drive their expansion. Activated ILC2s are central mediators of type 2 immune responses in the lung. Once activated, ILC2s and mast cells produce several cytokines including IL-13. IL-13 induces several cellular changes in the airways including goblet cell hyperplasia and mucus production, airway smooth muscle cell prolifera- tion, fibroblast proliferation and polarization of alternatively activated macrophages. IL-4, produced by TH2 cells and basophils, activates alternatively activated macrophages and eosinophils and induces IgE synthesis from B lymphocytes and plasma cells. IgE binds to FceRI receptors on human mast cells and basophils. IgE cross-linking by allergens induces the release of histamine, cysleukotrienes (Cys-LTs), PAF, prostaglandin $\mathrm{D}_{2}\left(\mathrm{PGD}_{2}\right)$, cytokines and chemokines that are responsible for some of the symptoms of asthma. way epithelial cells and smooth muscle cells [28]. The receptor is a heterodimer complex of IL-13R $\alpha$ and IL-4R $\alpha$. Circulating IL-13 firstly engages the IL-13Ral subunit and this event leads to the recruitment of IL-4Ra. The binding to theIL-13Ra1/IL-4Ra complex initiates the activation of multiple transduction pathways including ty- rosine kinase 2 (Tyk-2) and Janus kinase 1 (JAK1), which are associated with the IL-13R subunit [29]. The activation of these transduction systems induces the phosphorylation and activation of the proteins, signal transducer and activator of transcription 6 (STAT6) and insulin receptor substrate 2 (IRS-2) [29], which move from the cy- 
toplasm to the nucleus, and activate other transduction processes such as that of phosphatidylinositide 3-kinase (PI3-K) [30-32], serine-threonine protein kinase [33-36] and nuclear factor kappa-light-chain-enhancer of activated $B$ cells (NF- $\mathrm{kB}$ ) [37-39]. IL-13R has another receptor chain, IL-13Ra2, which does not activate transduction processes, but might play a regulatory role in IL-13-induced effects [40] and has been associated with human lung cancer as a potential target for novel therapies [41].

\section{Biomarkers}

As the role of specific cytokines in asthma became clearer, specific biomarkers of TH2 airway inflammation were identified. Biomarkers could help to stratify asthma into different subtypes (endotypes), reflecting the predominant pathophysiological mechanism, [42], helping to predict future risk [43] and target $\mathrm{TH} 2$-oriented therapies to patients that could respond. TH2-specific biomarkers identified so far include sputum/blood eosinophils, total serum IgE, the fraction of exhaled nitric oxide (FeNO) and bronchial epithelium-derived proteins.

The first biomarker identified and used to predict corticosteroid response was the eosinophil count in sputum and blood. Woodruff et al. [44] found that asthmatic patients with elevated bronchial expression of IL-5 and IL13 had higher blood eosinophil count than nonasthmatic controls. Some years later, Jia et al. [24] demonstrated a weak correlation between blood and airway eosinophil count, suggesting a limited sensitivity and reproducibility for this biomarker of TH2 inflammation. Furthermore, they presented experimental evidence that periostin is linked to IL-13 and TH2 inflammation.

Asthmatic patients can be classified in 2 main subgroups, as having eosinophilic or noneosinophilic asthma, according to a $2 \%$ bronchoscopy-based cut-off of sputum eosinophilia [45-47] found to be positively correlated with IL-13 expression in bronchial submucosa, thus indicating that sputum eosinophil count may be a marker of TH2 inflammation [48].

IL-4 and IL-13 also regulate the synthesis of IgE, and it could be hypothesized that total serum IgE is a biomarker for asthma phenotypes [49]. Unfortunately, total IgE has a low sensitivity and correlates poorly with eosinophilic inflammation [24].

IL-13 promotes NO-synthase activity and NO production, so elevated FeNO is a good index of TH2 inflammation and high levels of IL-13 in bronchial mucosa [50]. In addition, FeNO can also be used as a predictor of steroid

Anti-IL-13 and Anti-IL-4 Strategies in

Severe Asthma responsiveness more consistently than other parameters. It has been shown that patients with high FeNO levels respond better to steroid therapy, compared to those with lower levels of FeNO [51]. Similarly to FeNO, other evidence shows that the lower the level of eosinophils, the poorer the response to therapy $[52,53]$.

Other emerging biomarkers which could be helpful to stratify asthma patients are periostin and osteopontin. Both are matricellular proteins associated with $\mathrm{TH} 2$ inflammation due to their regulatory role in cell migration, extracellular matrix remodeling, growth and metastasis formation in various malignancies, transforming growth factor beta (TGF- $\beta$ ) concentration and collagen synthesis, that lead to airway remodeling [54-57]. In fact, TH2 high inflammation is characterized by high levels of expression of Il-13 and IL-4 inducible genes, including periostin [58]. Osteopontin and periostin sputum and serum concentration are associated with refractory eosinophilic airway inflammation and an accelerated decline in pulmonary function in patients undergoing inhaled corticosteroid (ICS) therapy [59-61]. Thus, they might be predictive of the response to anti-IL-13 therapy in ICS-insensitive patients, helping to stratify patients in which a relevant improvement of lung function is expected. Nagasaki et al. [62] studied 121 asthmatic patients receiving ICS treatment. They evaluated FeNO levels and serum periostin, and found that among 57 patients with high FeNO, 23 with concomitant high serum periostin had an accelerated decline in pulmonary function and more frequent and severe asthma exacerbations (despite highdose ICS therapy). These findings suggested that a combined evaluation of FeNO and serum periostin may be useful to identify ICS-insensitive patients.

All these data also suggest that these biomarkers provide complementary information about the different aspects of TH2 inflammation and, consequently, their use should be combined in clinical therapy [63].

\section{Anti-IL-13: Anrukinzumab, Lebrikizumab and Tralokinumab}

According to the important role of IL-13 in TH2 inflammation, a potential therapeutic strategy is to block the interaction of IL-13 with the specific receptor. Three monoclonal antibodies are currently under clinical evaluation.

Anrukinzumab is a humanized anti-IL-13 monoclonal antibody which acts to block the cytokine and prevent the activation of IL-13R $\alpha 1$ and IL-13R $\alpha 2$. Anrukinzumab has 
been tested in asthma and ulcerative colitis in phase II studies [64].

Lebrikizumab is an IgG4 humanized monoclonal antibody that blocks the signaling pathway through the IL4Ra/IL-13Ra1 heterodimer by binding soluble IL-13 and preventing its link to the receptor $[65,66]$. Corren et al. [6] performed a randomized, double-blind, placebo-controlled study of lebrikizumab in a population of 219 asthmatic patients with uncontrolled disease according to guidelines-recommended therapy. They found that, compared to the control population receiving placebo, patients on lebrikizumab at a dose of $250 \mathrm{mg}$ monthly for 6 months had a higher increase in forced expiratory volume in $1 \mathrm{~s}$ $\left(\mathrm{FEV}_{1}\right)$ versus at baseline. Furthermore, patients with higher serum levels of periostin before treatment had a greater improvement in lung function with lebrikizumab than patients with low periostin levels ( 8.2 vs. $1.6 \%$ higher than in the placebo group) and a greater reduction in FeNO levels in the high-periostin subgroup [6]. Another evidence of lebrikizumab efficacy came from Hanania et al. [67], who performed 2 randomized, multicenter, double-blind, placebo-controlled studies and found that treatment with lebrikizumab reduced asthma exacerbations, in particular in the subgroup of periostin-high patients, with a significant $60 \%$ reduction, versus the subgroup of periostin-low patients (a 5\% reduction). A second study performed by Noonan et al. [68] demonstrated the efficacy of lebrikizumab in terms of variations in $\mathrm{FEV}_{1}$, though this was not statistically significant, especially in patients with high levels of periostin. These data underlined the potential role of biomarkers, such as periostin, in tailoring an appropriate therapy. It would be of interest to know if all the patients with high periostin were responders or whether there were responders and nonresponders in this highperiostin group. Overall, the mentioned data would further support the discriminating role of high periostin as a predictive biomarker of response to lebrikizumab.

Tralokinumab is a human interleukin-13-neutralizing monoclonal IgG4 antibody which has been tested in severe uncontrolled asthma, ulcerative colitis and idiopathic pulmonary fibrosis. In a first study on moderate-tosevere asthma, Piper et al. [69] show good results about quality of life variation in subjects treated versus placebo group. Brightling et al. [70] performed another randomized, double-blind, placebo-controlled, parallel-group, multicenter, phase $2 \mathrm{~b}$ study, showing an acceptable tolerability and safety profile for tralokinumab but a nonsignificant reduction of asthma exacerbation rates. Some partially encouraging results were found in a subgroup of patients with a higher baseline amount of dipeptidyl pep-

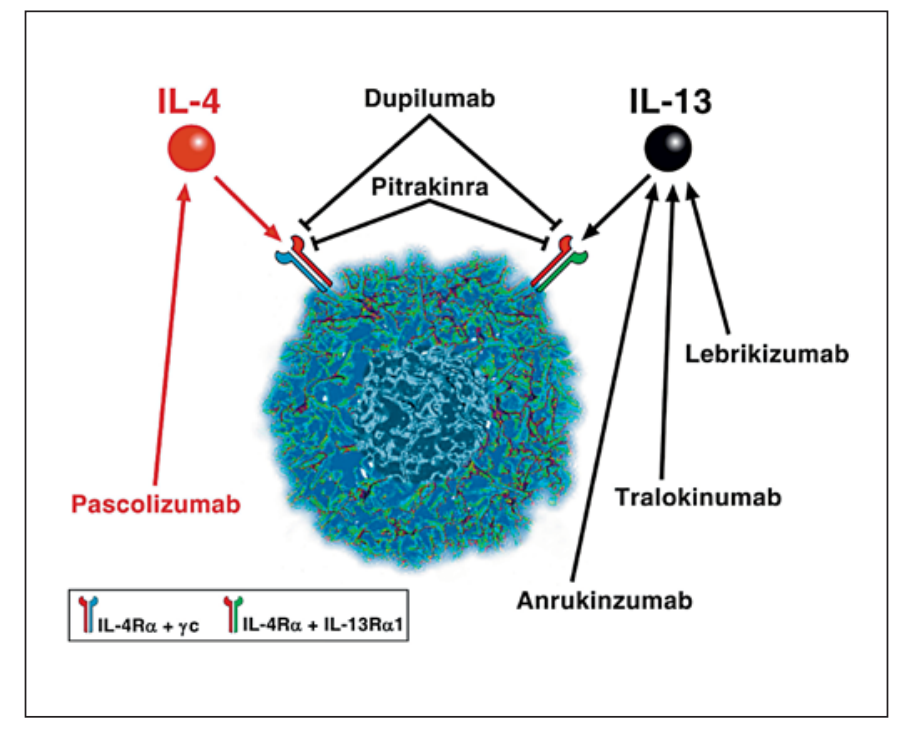

Fig. 2. Novel therapies for asthma targeting IL-4, IL-13 or their receptors. IL-4 signals via type I (IL- $4 \mathrm{R} \alpha+\gamma \mathrm{c})$ and type II receptors (IL-4R $\alpha+$ IL-13R $\alpha 1$ ) whereas IL-13 binds to type II receptors (IL$4 \mathrm{R} \alpha+\mathrm{IL}-13 \mathrm{R} \alpha 1)$ and to IL-13R 2 , which does not contain a transmembrane-signaling domain. Pascolizumab is a humanized antiIL-4 monoclonal antibody. Dupilumab and pitrakinra prevent IL-4/IL-13 interactions with IL-4R $\alpha$ of the IL-4 and IL-13 receptor complex. Lebrikizumab and tralokinumab are humanized monoclonal antibodies that target IL-13. Anrukinzumab is a humanized anti-IL-13 monoclonal antibody that inhibits the downstream signal of IL-13/IL-13Ra1 through a blocking interaction between IL13 and IL-4Ra.

tidase-4 (DPP-4) and periostin. These findings suggest a possible treatment effect in certain populations. This effect is also currently being analyzed in an ongoing phase 3 trial, together with the possible use of DPP-4 and periostin as biomarkers of interleukin-13 pathway activation. According to the role played by IL-13 in driving airways remodeling and fibroblast proliferation and the positive effect of tralokinumab in reducing IL-13 $[12,13]$ that contributes to airways inflammation, the use of tralokinumab is also currently being investigated in patients with idiopathic pulmonary fibrosis, especially in the rapidly progressive forms, where IL-13 is overexpressed in the lung tissue [71] (fig. 2).

\section{Anti-IL-4: Pascolizumab, Pitrakinra and Dupilumab}

IL-4, produced by T lymphocytes, activated mast cells and basophils, is involved in asthma via its role in many cellular mechanisms such as IgE production, eosinophil 
chemotaxis and the development of effector $\mathrm{T}$ cell responses [72]. One of the main roles of IL-4 is to promote the differentiation of undifferentiated $\mathrm{T}$ helper (TH0) cells to TH2 cells. The TH0 to TH2 skew favors the subsequent production of cytokines and mediators implicated in airway inflammation, obstruction and hyperresponsiveness, typical features of asthma [73]. IL-4 is also implicated in the production of IL-5. Thus, blocking IL-4 could be a reasonable strategy for controlling TH2 inflammation and reducing IL-5-dependent pulmonary eosinophilia [74]. Since IL-4 contributes to collagen production and fibronectin synthesis, fundamental events in airway remodeling, its inhibition could play a relevant role in preventing long-term airway remodeling in patients with severe asthma [75]. Different cells contribute to the production of IL- 4 in the airways, particularly eosinophils, basophils, mast cells and ILC2s [23]. Traditionally, TH2 cells are considered the major cellular source of the archetypal TH2 cytokines. Recently, ILC2s have been identified as an alternative source of IL-4, IL-5, IL-9 and IL-13 in response to circulating IL-25, IL-33 and TSLP. These cells are sufficient to induce an allergic response in mice [76]. The role of ILC2s in allergic human diseases characterized by eosinophilic inflammation, such as nasal polyps and atopic dermatitis, has recently been demonstrated [77]. Elevated levels of ILC2s in peripheral blood have also been found in asthmatic patients [78]. Liu et al. [79] have analyzed ILC2 levels in peripheral blood as an alternative and practical biomarker of eosinophilic inflammation in patients with mild-to-moderate asthma who could benefit from a TH2-targeted therapy, and found a $67.7 \%$ sensitivity and $95.3 \%$ specificity.

IL-4 inhibition can be done either by directly blocking IL-4 or indirectly by blocking the IL-4/IL-13 receptors. Hart et al. [80] evaluated the efficacy and safety of pascolizumab, a humanized anti-IL-4 monoclonal antibody, and its murine parent 3B9. Their study suggested that pascolizumab specifically binds IL-4 with a slow dissociation rate. The in vivo studies demonstrate a good tolerability, with a slight accumulation of the drug after chronic administration due to its long half-life. No toxicity or histopatological findings occurred. Although pascolizumab was found to be well tolerated in clinical trials, it did not produce a significant reduction in circulating $\operatorname{IgE}$, so the trials were aborted [81].

Pitrakinra, an IL-4R $\alpha /$ IL-13R $\alpha$ antagonist, was evaluated by inhalation and the subcutaneous route [82]. A double-blind trial with inhaled pitrakinra $(10 \mathrm{mg})$ failed to demonstrate measurable clinical efficacy of the agent, but asthma exacerbations were significantly reduced in a

Anti-IL-13 and Anti-IL-4 Strategies in Severe Asthma subgroup of patients with moderate-to-severe asthma with specific amino acid variants in the $3^{\prime}$ end of the IL4 Ra gene (IL4RA) [83]. Another clinical trial on pitrakinra's efficacy in atopic asthma patients demonstrated a lower pulmonary function reduction in the active group than in the control group [84].

Dupilumab is another monoclonal antibody, blocking the alpha subunit of IL-4/IL-13 receptor [85]. Wenzel et al. [86] performed a double-blind, placebo-controlled 2A phase clinical trial with dupilumab in adult patients with moderate-to-severe asthma symptoms and high blood eosinophils (>300 cells/ $\mu \mathrm{l})$ or sputum eosinophil level $(>3 \%)$. The number of asthma exacerbations was significantly lower in the active arm ( 3 vs. 23 ), and $\mathrm{FEV}_{1}$ significantly increased versus baseline. Although dupilumab causes a reduction in the biomarkers of $\mathrm{TH} 2$ inflammation, i.e. FeNO, eotaxin-3, thymus and activation-regulated chemokines (TARC), no significant effect on eosinophil blood count could be detected [87].

Anothercurrentlyongoingphase 3 trial(NCT02528214) is evaluating the effects of dupilumab in asthmatic patient with severe, systemic, steroid-dependent asthma. Dupilumab has also been proposed for other TH2-related diseases such as atopic dermatitis because of its role in the inhibition of IL-4 and IL-13 pathways. The provisional results of such studies are encouraging, and dupilumab seems to perform better than cyclosporine because of its lower adverse effects and good response to therapy [88]. Other studies assessing dupilumab in TH2-based diseases are investigating its possible use in nasal polyposis, chronic rhinosinusitis [89] and eosinophilic esophagitis (NCT02379052, phase 2) (table 1).

\section{Conclusions}

The path to personalized medicine is now a reality and exploring it would guide to a relevant revolution in the prescription modalities for asthma. The new concept is a shift from the era of 'one size fits all' to the era of 'one size does not fit all'. We are currently living in a situation offering multiple solutions to the problem of difficult-totreat asthma. According to the increasing importance of biomarkers for choosing the right drug, a further desirable therapeutic step would be to have ready-to-go solutions to be applied from the first visit. Rapid measurement of biomarkers (serum periostin, FeNo, eosinophils, etc.) would be fundamental in choosing the more appropriate drug for each individual patient. An alternative could be the use of monoclonal drugs in sequence ('ar-

Int Arch Allergy Immunol 2016;170:122-13 
Table 1. Principal clinical studies with biological drugs anti IL-4 and IL-13 in asthma

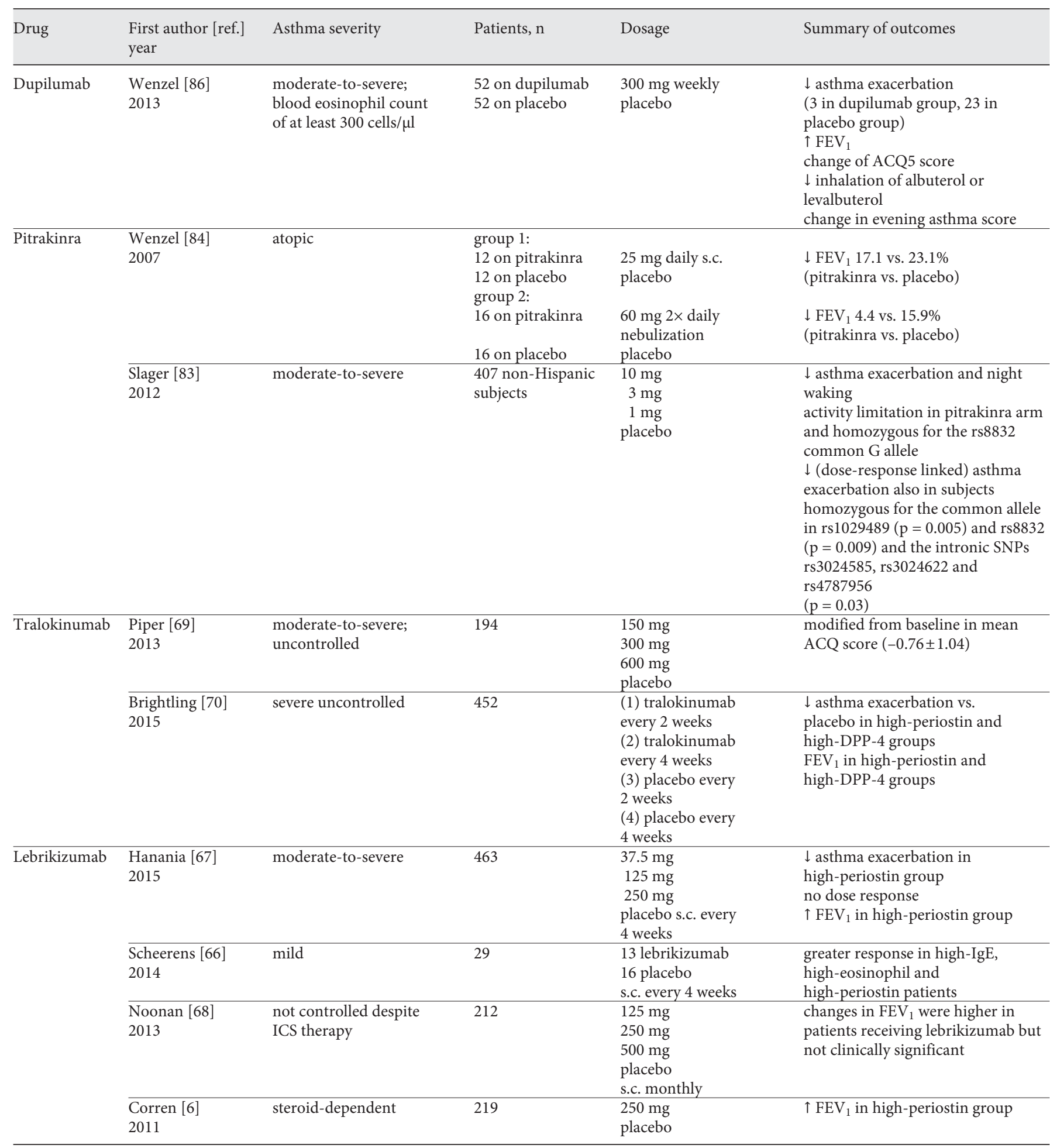

$\mathrm{ACQ}=$ Asthma control questionnaire; s.c. = subcutaneous. 
ticulated therapy'), first choosing a drug that acts via a particular immunological mechanism and then a second one that is specific for other pathways. For instance, in patients with an IgE concentration that is too high to use omalizumab, an anti-IL-4 could be proposed, and then once IgE levels are reduced, anti-IgE can be given. Another important unmet need is the duration of therapy. This is clearly emerging for omalizumab, where no standardized protocol is available on when to stop the treatment. An additional open question and possible target of further investigations is the use of molecules targeting different interleukins at the same time, so as to cover multiple therapeutic targets of inflammation simultaneously.

\section{Acknowledgement}

This paper has been partially supported by ARMIA (Associazione Ricerca Malattie Immunologiche e Allergiche) Genova.

\section{Disclosure Statement}

All authors stated no conflict of interests.

\section{References}

1 Centers for Disease Control and Prevention: Vital signs: asthma prevalence, disease characteristics, and self-management education: United States, 2001-2009. MMWR Morb Mortal Wkly Rep 2011;60:547-552.

2 Vianello A, Caminati M, Crivellaro M, El Mazloum R, Snenghi R, Rossi A, Festi G, Bovo C, Passalacqua G, Canonica GW, Senna G: Fatal asthma. Still an epidemic. Respir Med 2016, in press.

3 Accordini S, Corsico AG, Braggion M, Gerbase MW, Gislason D, Gulsvik A, Heinrich J, Janson C, Jarvis D, Jõgi R, Pin I, Schoefer Y, Bugiani M, Cazzoletti L, Cerveri I, Marcon A, de Marco R: The cost of persistent asthma in Europe: an international population-based study in adults. Int Arch Allergy Immunol 2013;160:93-101.

4 Bateman ED, Boushey HA, Bousquet J, Busse WW, Clark TJ, Pauwels RA, Pedersen SE; GOAL Investigators Group: Can guidelinedefined asthma control be achieved? The Gaining Optimal Asthma Control study. Am J Respir Crit Care Med 2004;170:836-844.

5 Haldar P, Brightling CE, Hargadon B, Gupta S, Monteiro W, Sousa A, Marshall RP, Bradding P, Green RH, Wardlaw AJ, Pavord ID: Mepolizumab and exacerbations of refractory eosinophilic asthma. N Engl J Med 2009;360: 973-984.

6 Corren J, Lemanske RF, Hanania NA, Korenblat PE, Parsey MV, Arron JR, Harris JM, Scheerens H, Wu LC, Su Z, Mosesova S, Eisner MD, Bohen SP, Matthews JG: Lebrikizumab treatment in adults with asthma. $\mathrm{N}$ Engl J Med 2011;365:1088-1098.

7 Chung KF: Targeting the interleukin pathway in the treatment of asthma. Lancet 2015;386: 1086-1096.

8 Gadani SP, Cronk JC, Norris GT, Kipnis J: Interleukin-4: a cytokine to remember. J Immunol 2012;189:4213-4219.
9 Derecki NC, Cardani AN, Yang CH, Quinnies KM, Crihfield A, Lynch KR, Kipnis J: Regulation of learning and memory by meningeal immunity: a key role for IL-4. J Exp Med 2010; 207:1067-1080.

10 Lynch MA: Age-related neuroinflammatory changes negatively impact on neuronal function. Front Aging Neurosci 2010;1:6.

11 McCormick SM, Heller NM: Commentary: IL-4 and IL-13 receptors and signaling. Cytokine 2015;75:38-50.

12 Doucet C, Brouty-Boyé D, Pottin-Clemenceau C, Jasmin C, Canonica GW, Azzarone B: IL-4 and IL-13 specifically increase adhesion molecule and inflammatory cytokine expression in human lung fibroblasts. B Int Immunol 1998;10:1421-1433.

13 Doucet C, Brouty-Boyé D, Pottin-Clémenceau C, Canonica GW, Jasmin C, Azzarone B: Interleukin (IL) 4 and IL-13 act on human lung fibroblasts. Implication in asthma. J Clin Invest 1998;101:2129-2139.

14 Richter A, Puddicombe SM, Lordan JL, Bucchieri F, Wilson SJ, Djukanovic R, Dent G, Holgate ST, Davies DE: The contribution of interleukin (IL)-4 and IL-13 to the epithelialmesenchymal trophic unit in asthma. Am J Respir Cell Mol Biol 2001;25:385-391.

15 Bossé Y, Thompson C, Audette K, Stankova J, Rola-Pleszczynski M: Interleukin-4 and interleukin-13 enhance human bronchial smooth muscle cell proliferation. Int Arch Allergy Immunol 2008;146:138-148.

16 Kondo M, Tamaoki J, Takeyama K, Isono K, Kawatani K, Izumo T, Nagai A: Elimination of IL-13 reverses established goblet cell metaplasia into ciliated epithelia in airway epithelial cell culture. Allergol Int 2006;55:329-336.

17 Chiba Y, Nakazawa S, Todoroki M, Shinozaki K, Sakai H, Misawa M: Interleukin-13 augments bronchial smooth muscle contractility with an up-regulation of RhoA protein. Am J Respir Cell Mol Biol 2009;40:159-167.
18 Punnonen J, Aversa G, Cocks BG, McKenzie AN, Menon S, Zurawski G, de Waal Malefyt $\mathrm{R}$, de Vries JE: Interleukin 13 induces interleukin 4-independent IgG4 and IgE synthesis and CD23 expression by human B cells. Proc Natl Acad Sci USA 1993;90:3730-3734.

19 Horie S, Okubo Y, Hossain M, Sato E, Nomura $\mathrm{H}$, Koyama S, Suzuki J, Isobe M, Sekiguchi M: Interleukin-13 but not interleukin-4 prolongs eosinophil survival and induces eosinophil chemotaxis. Intern Med 1997;36: 179-185.

20 Luttmann W, Knoechel B, Foerster M, Matthys H, Virchow JC Jr, Kroegel C: Activation of human eosinophils by IL-13. Induction of CD69 surface antigen, its relationship to messenger RNA expression, and promotion of cellular viability. J Immunol 1996;157:16781683.

21 Davies DE, Wicks J, Powell RM, Puddicombe SM, Holgate ST: Airway remodeling in asthma: new insights. J Allergy Clin Immunol 2003;111:215-225; quiz 226.

22 Holgate ST: Innate and adaptive immune responses in asthma. Nat Med 2012;18:673683.

23 KleinJan A: Airway inflammation in asthma: key players beyond the Th2 pathway. Curr Opin Pulm Med 2016;22:46-52.

24 Jia G, Erickson RW, Choy DF, Mosesova S, Wu LC, Solberg OD, Shikotra A, Carter R, Audusseau S, Hamid Q, Bradding P, Fahy JV, Woodruff PG, Harris JM, Arron JR; Periostin is a systemic biomarker of eosinophilic airway inflammation in asthmatic patients. Bronchoscopic Exploratory Research Study of Biomarkers in Corticosteroid-refractory Asthma (BOBCAT) Study Group. J Allergy Clin Immunol 2012;130:647-654.

25 Nelms K, Keegan AD, Zamorano J, Ryan JJ, Paul WE: The IL-4 receptor: signaling mechanisms and biologic functions. Annu Rev Immunol 1999;17:701-738. 
26 Oh CK, Geba GP, Molfino N: Investigational therapeutics targeting the IL-4/IL-13/STAT-6 pathway for the treatment of asthma. Eur Respir Rev 2010;19:46-54.

27 Gour N, Wills-Karp M: IL-4 and IL-13 signaling in allergic airway disease. Cytokine 2015; 75:68-78.

28 Corren J: Role of interleukin-13 in asthma. Curr Allergy Asthma Rep. 2013;13:415-420.

29 Chiba Y, Goto K, Misawa M: Interleukin13-induced activation of signal transducer and activator of transcription 6 is mediated by an activation of Janus kinase 1 in cultured human bronchial smooth muscle cells. Pharmacol Rep 2012;64:454-458.

30 Sun XJ, Wang L-M, Zhang Y, Yenush L, Myers MG Jr, Glasheen E, Lane WS, Pierce JH, White MF: Role of IRS-2 in insulin and cytokine signalling. Nature 1995;377:173-177.

31 Dhand R, Hiles I, Panayotou G, Roche S, Fry MJ, Gout I, Totty NF, Truong O, Vicendo P, Yonezawa $\mathrm{K}$, et al: PI 3-kinase is a dual specificity enzyme: autoregulation by an intrinsic protein-serine kinase activity. EMBO J 1994 13:522-533.

32 Ruckerl D, Jenkins SJ, Laqtom NN, Gallagher IJ, Sutherland TE, Duncan S, Buck AH, Allen JE: Induction of IL-4Ralpha-dependent microRNAs identifies PI3K/Akt signaling as essential for IL-4-driven murine macrophage proliferation in vivo. Blood 2012;120:23072316.

33 Heller NM, Qi X, Gesbert F, Keegan AD: The extracellular and transmembrane domains of the gammaC and interleukin (IL)-13 receptor alphal chains, not their cytoplasmic domains, dictate the nature of signaling responses to IL-4 and IL-13. J Biol Chem 2012;287:3194831961.

34 Karlsson HR, Zierath J: Insulin signaling and glucose transport in insulin resistant human skeletal muscle. Cell Biochem Biophys 2007; 48:103-113

35 Landis J, Shaw LM: Insulin receptor substrate-2 mediated phosphatidylinositol-3-kinase signaling selectively inhibits glycogen synthase kinase-3b to regulate aerobic glycolysis. J Biol Chem 2014;289:18603-18613.

36 Russo SJ, Bolanos CA, Theobald DE, DeCarolis NA, Renthal W, Kumar A, Winstanley CA, Renthal NE, Wiley MD, Self DW, Russell DS, Neve RL, Eisch AJ, Nestler EJ: IRS2-Akt pathway in midbrain dopamine neurons regulates behavioral and cellular responses to opiates. Nat Neurosci 2007;10:93-99.

37 Mikita T, Campbell D, Wu P, Williamson K, Schindler U: Requirements for interleukin4 -induced gene expression and functional characterization of Stat6. Mol Cell Biol 1996; 16:5811-5820.

38 Shen $\mathrm{C}-\mathrm{H}$, Stavnezer J: Interaction of stat6 and NF- $\kappa \mathrm{B}$ : direct association and synergistic activation of interleukin-4-induced transcription. Mol Cell Biol 1998;18:3395-3404.
39 Delphin S, Stavnezer J: Characterization of an interleukin 4 (IL-4) responsive region in the immunoglobulin heavy chain germline epsilon promoter: regulation by NF-IL-4, a C/ EBP family member and NF- $\mathrm{BB} / \mathrm{p} 50$. J Exp Med 1995;181:181-192.

40 Zheng T, Liu W, Oh SY, Zhu Z, Hu B, Homer RJ, Cohn L, Grusby MJ, Elias JA: IL-13 receptor alpha2 selectively inhibits IL-13-induced responses in the murine lung. J Immunol 2008; 180:522-529.

41 Xie M, Wu XJ, Zhang JJ, He CS: IL-13 receptor $\alpha 2$ is a negative prognostic factor in human lung cancer and stimulates lung cancer growth in mice. Oncotarget 2015;6:3290232913.

42 Bartminski G, Crossley M, Turcanu V: Novel biomarkers for asthma stratification and personalized therapy. Expert Rev Mol Diagn 2015; 15:415-430

43 Muñoz X, Bustamante V, Lopez-Campos JL, Cruz MJ, Barreiro E: Usefulness of noninvasive methods for the study of bronchial inflammation in the control of patients with asthma. Int Arch Allergy Immunol 2015;166: $1-12$.

44 Woodruff PG, Modrek B, Choy DF, Jia G, Abbas AR, Ellwanger A, Koth LL, Arron JR, Fahy JV: T-helper type 2-driven inflammation defines major subphenotypes of asthma. Am J Respir Crit Care Med 2009;180:388-395.

45 Wenzel SE, Schwartz LB, Langmack EL, Halliday JL, Trudeau JB, Gibbs RL, Chu HW: Evidence that severe asthma can be divided pathologically into two inflammatory subtypes with distinct physiologic and clinical characteristics. Am J Respir Crit Care Med 1999;160:1001-1008.

46 Spanevello A, Confalonieri M, Sulotto F, Romano F, Balzano G, Migliori GB, Bianchi A, Michetti G: Induced sputum cellularity. Reference values and distribution in normal volunteers. Am J Respir Crit Care Med 2000;162: 1172-1174.

47 Dente FL, Latorre M, Novelli F, Cianchetti S, Bartoli ML, Bacci E, Di Franco A, Vagaggini B, Celi A, Paggiaro P: Can Sputum eosinophilia be a constant feature in severe refractory asthmatics? A 3-year longitudinal study. Int Arch Allergy Immunol 2015; 166:287-290.

48 Saha SK, Berry MA, Parker D, Siddiqui S, Morgan A, May R, Monk P, Bradding P, Wardlaw AJ, Pavord ID, Brightling CE: Increased sputum and bronchial biopsy IL-13 expression in severe asthma. J Allergy Clin Immunol 2008;121:685-691.

49 Kuiper S, Muris JW, Dompeling E, van Schayck CP, Schönberger HJ, Wesseling G, Knottnerus JA: Association between first-degree familial predisposition of asthma and atopy (total IgE) in newborns. Clin Exp Allergy 2006;36:594-601
50 Chibana K, Trudeau JB, Mustovich AT, Hu H, Zhao J, Balzar S, Chu HW, Wenzel SE: IL13 induced increases in nitrite levels are primarily driven by increases in inducible nitric oxide synthase as compared with effects on arginases in human primary bronchial epithelial cells. Clin Exp Allergy 2008;8:936-946.

51 Smith AD, Cowan JO, Brassett KP, Filsell S, McLachlan C, Monti-Sheehan G, Peter Herbison G, Robin Taylor D: Exhaled nitric oxide: a predictor of steroid response. Am J Respir Crit Care Med 2005;172:453-459.

52 Brown HM: Treatment of chronic asthma with prednisolone; significance of eosinophils in the sputum. Lancet 1958;2:1245-1247.

53 Pavord ID, Brightling CE, Woltmann G, Wardlaw AJ: Non-eosinophilic corticosteroid unresponsive asthma. Lancet 1999;353:22132214.

54 Gillan L, Matei D, Fishman DA, Gerbin CS, Karlan BY, Chang DD: Periostin secreted by epithelial ovarian carcinoma is a ligand for alpha(V)beta(3) and alpha(V)beta(5) integrins and promotes cell motility. Cancer Res 2002;62:5358-5364.

55 Wang X, Liu J, Wang Z, Huang Y, Liu W, Zhu X, Cai Y, Fang X, Lin S, Yuan L, Ouyang G: Periostin contributes to the acquisition of multipotent stem cell-like properties in human mammary epithelial cells and breast cancer cells. PLoS One 2013;8:e72962.

56 Sidhu SS, Yuan S, Innes AL, Kerr S, Woodruff PG, Hou L, Muller SJ, Fahy JV: Roles of epithelial cell-derived periostin in TGF-beta activation, collagen production, and collagen gel elasticity in asthma. Proc Natl Acad Sci USA 2010;107:14170-14175.

57 Xanthou G, Alissafi T, Semitekolou M, Simoes DC, Economidou E, Gaga M, Lambrecht BN, Lloyd CM, Panoutsakopoulou V: Osteopontin has a crucial role in allergic airway disease through regulation of dendritic cell subsets. Nat Med 2007;13:570-578.

58 Takayama G, Arima K, Kanaji T, Toda S, Tanaka H, Shoji S, McKenzie AN, Nagai H, Hotokebuchi T, Izuhara K: Periostin: a novel component of subepithelial fibrosis of bronchial asthma downstream of IL-4 and IL-13 signals. J Allergy Clin Immunol 2006;118:98104

59 Kanemitsu Y, Matsumoto H, Izuhara $\mathrm{K}$ Tohda Y, Kita H, Horiguchi T, Kuwabara K, Tomii K, Otsuka K, Fujimura M, Ohkura N, Tomita K, Yokoyama A, Ohnishi H, Nakano Y, Oguma T, Hozawa S, Nagasaki T, Ito I, Oguma $\mathrm{T}$, Inoue $\mathrm{H}$, Tajiri $\mathrm{T}$, Iwata $\mathrm{T}$, Izuhara Y, Ono J, Ohta S, Tamari M, Hirota T, Yokoyama T, Niimi A, Mishima M: Increased periostin associates with greater airflow limitation in patients receiving inhaled corticosteroids. J Allergy Clin Immunol 2013;132:305312

60 Delimpoura V, Bakakos P, Tseliou E, Bessa V, Hillas G, Simoes DC, Papiris S, Loukides S: Increased levels of osteopontin in sputum supernatant in severe refractory asthma. Thorax 2010;65:782-786. 
61 Nagasaki T, Matsumoto H, Kanemitsu Y, Izuhara K, Tohda Y, Kita H, Horiguchi T, Kuwabara K, Tomii K, Otsuka K, Fujimura M, Ohkura N, Tomita K, Yokoyama A, Ohnishi H, Nakano Y, Oguma T, Hozawa S, Ito I, Oguma $\mathrm{T}$, Inoue $\mathrm{H}$, Tajiri $\mathrm{T}$, Iwata $\mathrm{T}$, Izuhara $\mathrm{Y}$, Ono J, Ohta S, Yokoyama T, Niimi A, Mishima M: Integrating longitudinal information on pulmonary function and inflammation using asthma phenotypes. J Allergy Clin Immunol 2014; 133:1474-1477.

62 Nagasaki T, Matsumoto H, Kanemitsu Y, Izuhara K, Tohda Y, Horiguchi T, Kita H, Tomii K, Fujimura M, Yokoyama A, Nakano Y, Hozawa S, Ito I, Oguma T, Izuhara Y, Tajiri T, Iwata $\mathrm{T}$, Ono J, Ohta S, Yokoyama T, Niimi A, Mishima M: Using exhaled nitric oxide and serum periostin as a composite marker to identify severe/steroid-insensitive asthma. Am J Respir Crit Care Med 2014;190:14491452.

63 De Ferrari L, Chiappori A, Bagnasco D, Riccio AM, Passalacqua G, Canonica GW: Molecular phenotyping and biomarker development: are we on our way towards targeted therapy for severe asthma? Expert Rev Respir Med 2016;10:29-38.

64 Hua F, Ribbing J, Reinisch W, Cataldi F, Martin S: A pharmacokinetic comparison of anrukinzumab, an anti- IL-13 monoclonal antibody, among healthy volunteers, asthma and ulcerative colitis patients. Br J Clin Pharmacol 2015;80:101-109.

65 Ultsch M, Bevers J, Nakamura G, Vandlen R, Kelley RF, Wu LC, Eigenbrot C: Structural basis of signaling blockade by anti-IL-13 antibody lebrikizumab. J Mol Biol 2013;425: 1330-1339.

66 Scheerens H, Arron JR, Zheng Y, Putnam WS, Erickson RW, Choy DF, Harris JM, Lee J, Jarjour NN, Matthews JG: The effects of lebrikizumab in patients with mild asthma following whole lung allergen challenge. Clin Exp Allergy 2014;44:38-46.

67 Hanania NA, Noonan M, Corren J, Korenblat P, Zheng Y, Fischer SK, Cheu M, Putnam WS, Murray E, Scheerens H, Holweg CT, Maciuca R, Gray S, Doyle R, McClintock D, Olsson J, Matthews JG, Yen K: Lebrikizumab in moderate-to-severe asthma: pooled data from two randomised placebo-controlled studies. Tho$\operatorname{rax} 2015 ; 70: 748-756$.

68 Noonan M, Korenblat P, Mosesova S, Scheerens $\mathrm{H}$, Arron JR, Zheng Y, Putnam WS, Parsey MV, Bohen SP, Matthews JG: Doseranging study of lebrikizumab in asthmatic patients not receiving inhaled steroids. J Allergy Clin Immunol 2013;132:567-574.e12.
69 Piper E, Brightling C, Niven R, Oh C, Faggioni R, Poon K, She D, Kell C, May RD, Geba GP, Molfino NA: A phase II placebocontrolled study of tralokinumab in moderate-to-severe asthma. Eur Respir J 2013;41: 330-338.

70 Brightling CE, Chanez P, Leigh R, O’Byrne PM, Korn S, She D, May RD, Streicher K, Ranade K, Piper E: Efficacy and safety of tralokinumab in patients with severe uncontrolled asthma: a randomised, double-blind, placebo-controlled, phase $2 \mathrm{~b}$ trial. Lancet Respir Med 2015;3:692-701.

71 Murray LA, Zhang H, Oak SR, Coelho AL, Herath A, Flaherty KR, Lee J, Bell M, Knight DA, Martinez FJ, Sleeman MA, Herzog EL, Hogaboam CM: Targeting interleukin-13 with tralokinumab attenuates lung fibrosis and epithelial damage in a humanized SCID idiopathic pulmonary fibrosis model. Am J Respir Cell Mol Biol 2014;50:985-994.

72 Ricci M: IL-4: a key cytokine in atopy. Clin Exp Allergy 1994;24:801-812. Pauwels RA, Brusselle GG, Tournoy KG, Lambrecht BN, Kips JC: Cytokines and their receptors as therapeutic targets in asthma. Clin Exp Allergy 1998;28(suppl 3):1-5.

73 Ricci M, Matucci A, Rossi O: IL-4 as a key factor influencing the development of allergenspecific Th2-like cells in atopic individuals. J Invest Allergol Clin Immunol 1997;7:144150.

74 Garlisi CG, Kung TT, Wang P Minnicozzi M, Umland SP, Chapman RW, Stelts D, Crawley Y, Falcone A, Myers JG, Jones H, Billah MM, Kreutner W, Egan RW: Effects of chronic anti-interleukin-5 monoclonal antibody treatment in a murine model of pulmonary inflammation. Am J Respir Cell Mol Biol 1999; 20:248-255.

75 Buttner C, Skupin A, Reimann T, Rieber EP, Unteregger G, Geyer P, Frank KH: Local production of interleukin-4 during radiation-induced pneumonitis and pulmonary fibrosis in rats: macrophages as a prominent source of interleukin-4. Am J Respir Cell Mol Biol 1997; 17:315-325.

76 Barlow JL, McKenzie AN: Type-2 innate lymphoid cells in human allergic disease. Curr Opin Allergy Clin Immunol 2014;14:397403.

77 Walford HH, Lund SJ, Baum RE, White AA, Bergeron CM, Husseman J, Bethel KJ, Scott DR, Khorram N, Miller M, Broide DH, Doherty TA: Increased ILC2s in the eosinophilic nasal polyp endotype are associated with corticosteroid responsiveness. Clin Immunol 2014;155:126e135.

78 Bartemes KR, Kephart GM, Fox SJ, Kita H: Enhanced innate type 2 immune response in peripheral blood from patients with asthma. J Allergy Clin Immunol 2014;134:671-678.e4.
79 Liu T, Wu J, Zhao J, Wang J, Zhang Y, Liu L, Cao L, Liu Y, Dong L: Type 2 innate lymphoid cells: A novel biomarker of eosinophilic airway inflammation in patients with mild to moderate asthma. Respir Med 2015;109: 1391-1396.

80 Hart TK, Blackburn MN, Brigham-Burke M, Dede K, Al-Mahdi N, Zia-Amirhosseini P, Cook RM: Preclinical efficacy and safety of pascolizumab (SB 240683): a humanized antiinterleukin-4 antibody with therapeutic potential in asthma. Clin Exp Immunol 2002; 130:93-100.

81 Walker BL, Leigh R: Use of biologicals as immunotherapy in asthma and related diseases. Expert Rev Clin Immunol 2008;4:743-756.

82 Pelaia G, Vatrella A, Maselli R: The potential of biologics for the treatment of asthma. Nat Rev Drug Discov 2012;11:958-972.

83 Slager RE, Otulana BA, Hawkins GA, Yen YP, Peters SP, Wenzel SE, Meyers DA, Bleecker ER: IL-4 receptor polymorphisms predict reduction in asthma exacerbations during response to an anti-IL-4 receptor $\alpha$ antagonist. J Allergy Clin Immunol 2012;130:516-522.e4.

84 Wenzel S, Wilbraham D, Fuller R, Getz EB, Longphre M: Effect of an interleukin-4 variant on late phase asthmatic response to allergen challenge in asthmatic patients: results of two phase 2a studies. Lancet 2007;370:14221431.

85 Wechsler ME: Inhibiting interleukin-4 and interleukin-13 in difficult-to-control asthma. N Engl J Med 2013;368:2511-2513.

86 Wenzel S, Ford L, Pearlman D, Spector S, Sher L, Skobieranda F, Wang L, Kirkesseli S, Rocklin R, Bock B, Hamilton J, Ming JE, Radin A, Stahl N, Yancopoulos GD, Graham N, Pirozzi G: Dupilumab in persistent asthma with elevated eosinophil levels. N Engl J Med 2013; 368:2455-2466.

87 Vatrella A, Fabozzi I, Calabrese C, Maselli R, Pelaia G: Dupilumab: a novel treatment for asthma. J Asthma Allergy 2014;7:123-130.

88 Tsianakas A, Ständer S: Dupilumab: a milestone in the treatment of atopic dermatitis. Lancet 2016;387:4-5.

89 Bachert C, Mannent L, Naclerio RM, Mullol J, Ferguson BJ, Gevaert P, Hellings P, Jiao L, Wang L, Evans RR, Pirozzi G, Graham NM, Swanson B, Hamilton JD, Radin A, Gandhi NA, Stahl N, Yancopoulos GD, Sutherland R: Effect of subcutaneous dupilumab on nasal polyp burden in patients with chronic sinusitis and nasal polyposis. A randomized clinical trial. JAMA 2016;315:469-479.
Anti-IL-13 and Anti-IL-4 Strategies in Severe Asthma
Int Arch Allergy Immunol 2016;170:122-131 DOI: $10.1159 / 000447692$ 